\title{
Customer satisfaction with Tokyo Metropolitan Government ward office counter services: confirmatory factor analysis of question grouping and principal component regression analysis
}

Yasutoshi Moteki ( $\nabla$ moteki@hiroshima-u.ac.jp )

Hiroshima University https://orcid.org/0000-0001-7763-670X

\section{Research Article}

Keywords: counter service, customer satisfaction, direct experience, factor analysis, local governments, Japan

Posted Date: December 28th, 2021

DOI: https://doi.org/10.21203/rs.3.rs-1204123/v1

License: (c) (1) This work is licensed under a Creative Commons Attribution 4.0 International License. Read Full License 


\section{Abstract}

This study examines the determinants of service satisfaction among users of a ward office in Tokyo using a two-part questionnaire. The questionnaire comprised three main categories of multiple-choice questions: A) facility equipment (physical elements in the government office), B) staff responses, and C) service delivery (e.g., promptness of services, whether visitors completed their scheduled errands). In addition, three groups of questions related to the personalities of the users of each facility were investigated. During a one-day survey period, responses were collected from 400 women, aged 30-59 years, who had visited a ward office in the Tokyo Metropolitan Area over a one-month period. This age segment was studied because it is the major segment of the panel of the Internet research firm used. First, factor analysis was used to check the appropriateness of the grouping of questions, and it was confirmed that the three groups were appropriate based on eigenvalues and scree plots. Then, to examine the determinants of counter service customer satisfaction, principal component analysis and multiple regression analysis were conducted for each question category. The regression analysis using the three main question groups and three other respondents' personality-related question groups indicated that group $C$ (service delivery quality) had the strongest influence on the dependent variable, followed by group B and group A. The adjusted $R^{2}$ value was .70 . This result is consistent with the results of the author's surveys of government offices in urban areas conducted for Higashihiroshima City Hall and of ward offices in Osaka.

\section{Introduction}

In the world of public administration, the concept of governance has attracted considerable attention in recent decades. The first issue of the journal Governance: An International Journal of Policy, Administration, and Institutions (1988) contained a number of articles on the changing relationship between politics and public administration, which has been the subject of ongoing debate in American public administration research, such as in Campbell and Peters (1988). Subsequent research on public administration has been divided into two major categories: (1) the use of governance as an abstract concept that represents a change in the way the entire administration is governed, and (2) the use of governance as a concrete concept in the same way as corporate governance, in the sense of compliance with laws and regulations and proper operational management of organizations. Example of the former are Compton, et.al. (2021) and Dickson (2016), and examples of the latter are Brunet and Aubry (2016) and Almqvist et al. (2013). When the concept of governance is used in the private sector, it is often used in a specific meaning related to the latter fiscal accountability. While governance in the corporate sector means enacting rules and strengthening the authority of shareholders and boards of directors, discussions of governance in the government sector often mean a retreat or reduction in the oversight and role of government. Along with the spread of the concept of governance, a major area of growth in the public administration research has been work on New Public Management (NPM; e.g., Osborne, 2006), that is, the introduction of private-sector management methods into the field of public 
administration, and is characterized by the employment of arguments from economics, especially public economics based on modern economics, such as principal-agent theory, into public administration.

Building on these concepts, the idea of "New Public Service" has begun to spur discussions on how to improve management by thinking that the private and public sector organizations are similar in respect to the aspect of providing value to service purchasers (Dickson, 2016; Denhardt \& Denhardt, 2015). A service means the provision of an intangible good, and its value is measured by focusing on its quality of service; the concept of customer satisfaction or citizen satisfaction is therefore emphasized (Swallehe, 2021). Singh and Slack (2020) discuss the effect of new public management-type administrative reforms on citizens' perceptions of administrative service quality using quantitative methods (based on SERVQUAL) and qualitative methods, through case studies. Box (1999), through the survey of literature in American public administrative studies, discusses the social and political context and the background against which government agencies are exposed to market pressures, such as emphasis on customer perspectives. There are many criticisms of this view (e.g., Thomas (2013), Brown (2007), who points out the risks of treating citizens simply as customers, and Atreya \& Armstrong (2002), who introduce and review a number of critical papers on New Public Management). The view that citizens, who are the customers of the government, are the same as those of private companies, has become wide-spread in this trend.

In this context, in various countries, customer satisfaction surveys using the same methods as those used in the private sector, both in practice and in research, are also being conducted in the government sector. Haywood-Farmer (1988) points out that the study of quality and quality control became prominent again in the 1980s in large part because of the interest in Japanese-style management. Recently, there has been a growing body of research on satisfaction in individual policy areas; Deb and Ahmed (2018) studied city bus services in Agartala, India, using factor analysis, linear regression analysis, and structural equation modelling.

This study conducted an online questionnaire survey collaborating with Rakuten Insight corporation on December 1, 2021, among female residents of the 23 special wards of the Tokyo Metropolitan Area, aged 30-59 years, who had visited a ward office in Tokyo over a one-month period. They responded to questions related to their level of satisfaction with the counter services provided at these ward offices. Rakuten Insight registered respondents as panel members in advance from Rakuten Ichiba shopping mall members. The Rakuten Group originated with this Japanese internet shopping mall site, which has a large proportion of middle-aged female members. It is beneficial to focus on this age group because the panel was drawn from the users of the Rakuten Ichiba online shopping mall, catering mainly to middleaged people. The Tokyo Metropolitan Area is the largest urban area in Japan, organized under the To system ("Special Treatment System for the Capital City"), which is different from the organization of other large cities in Japan. The Tokyo metropolitan government system is one of the special exceptions applied to major cities under the Local Autonomy Law. The local system in Japan is basically a two-tier system (prefectures/municipalities). The Tokyo Metropolitan Government is the upper tier of wide-area municipalities that correspond to prefectures, and special wards are placed in the lower tier in place of 
municipalities. The administrative City of Tokyo was abolished in July 1943, during the Second World War, and wards were newly established, subject to the special metropolitan government system (To system), which limited Tokyo's autonomy as the capital (Tokyo Metropolitan Government, 2020). As a result, the city of Tokyo, headed by a publicly elected mayor, was abolished (For the history of the special districts described below, see Public Interest Incorporated Foundation Special Wards Council, 2019.). Each ward was merely an administrative division and was not a municipality, as the head was not elected by the public. Tokyo's wards regained much of their autonomy after World War II, under the name of special wards in 1952. While the status of special wards was clearly positioned in the Local Autonomy Law as internal organizations of the Tokyo Metropolitan Government, in April 1975, as a result of the amendment of the Local Autonomy Law, a new special ward system was initiated and ward mayors were publicly elected, similar to other basic municipalities such as city, towns and villages, which have the character of basic municipalities with a publicly elected mayor. In sum, the special wards of the Tokyo Metropolitan Government now have almost the same authority as city municipalities with publicly elected mayors and they perform the same functions for the residents. As of March 2018, 9,482,125 people lived in the 23 wards of Tokyo, while the population of Tokyo as a whole was 13,754,043 (Tokyo Metropolitan Government, 2018). More than $10 \%$ of Japan's total population is concentrated in Tokyo. In the two-tiered system of local autonomy, the Tokyo metropolitan government is responsible for the administrative services of the upper-tiered prefectural governments (e.g., approval of hospitals, operation of high schools), while the lower-tiered local governments (municipalities equivalent to cities, towns and villages in other prefectures), the special wards, provide familiar administrative services such as resident registration, garbage collection, and operation of elementary and junior high schools.

In this study, in addition to the three groups of questions used in the author's previous studies (Moteki, 2021), A (facility equipment), B (staff response), and C (service delivery), three additional groups of questions related to the personalities and thoughts of the facility users were added. B (staff response) is a question group related to the explanation of the counter staff and their treatment of customers. $\mathrm{C}$ (service delivery) is a question group about the status of service delivery related to the completion of errands at the ward office, the speed of those errands, and the waiting time. Research on customer satisfaction in both the private and government sectors is no longer limited to the provision of services and their quality, but also includes the attributes and psychological state of service providers and purchasers (users) as a factor in customer satisfaction (e.g., Nazi, 2010). Yu et al. (2011) quantitatively examined the effect of service recipient attributes such as household income on satisfaction with the service. Vermeeren et al. (2011) used the metaphor of a "satisfaction mirror," meaning that employee satisfaction influences customer satisfaction, and mentioned that educating employees about the significance of a company's business programs is important as an instrument of internal marketing. They examine data on work environment characteristics, job satisfaction, and customer satisfaction of frontline employees in 35 Dutch municipalities in relation to data on customer satisfaction. Smith (2020) examined the effect of service purchasers' personality attributes on satisfaction and brand loyalty for cell phone services. Rha (2012) conducted a questionnaire survey in South Korea, in the field of social work, childcare, and healthcare services, using a 5-point questionnaire based on SERVPERF. In addition to 
service quality and service delivery, "relationship quality," defined as "the depth and climate of the relationship between suppliers that participate in the public service delivery" and based on Johnson (1999), was examined, and it was argued that this variable could influence customer satisfaction as a mediating variable.

Professor Yu Noda (Noda, 2013; 2014; 2019; 2021) has published extensive research on Japanese citizen satisfaction with public administration in English. The author's research shares Professor Noda's awareness of the problem, but is on a more specific level and differs in terms of methodology.

Specifically, the author's study employed a questionnaire survey to examine the determinants of customer satisfaction with the counter services provided at local government offices, using a multi-group questionnaire developed from SERVQUAL (to be discussed later) to quantitatively and concretely examine the factors that contribute to satisfaction. It applies the multi-group question survey method with a 7point scale, which is widely used in the field of business administration, to public administration, and conducts empirical research at the level of specific government facilities. Everitt (2005) also mentions performing principal component analysis on multiple question items belonging to several categories before multiple regression analysis. This avoids the risk of multicollinearity between each question item. By surveying specific users of Japanese government offices about their experiences using a questionnaire consisting of three groups of questions (a simplified version of SERVQUAL using five groups of questions), I would like to show that the service quality evaluation methods widely applied in the private sector can also be used in the public sector. This is accomplished by examining the results of confirmatory factor analysis and regression analysis, especially coefficients of determination and standardized partial regression coefficients.

\section{Literature Review}

The study of citizen satisfaction with services in public administration has been influenced by similar studies in the private sector, which developed earlier. Several important studies on customer satisfaction in public administration have been reviewed previously by Moteki (2020). In the following review, I will focus on particularly important literature, as well as new literature not previously covered. Wagenheim and Reurink (1991) explained the difference between internal and external customers (employees in other departments; citizens), and discussed that the satisfaction of the service needs of these two groups leads to organizational efficiency and effectiveness.

Parasuraman et al.'s (1985) SERVQUAL methods are widely used in both public and private organizations to examine service quality and customer satisfaction. 1985 is considered the year of the first appearance of SERQUAL (Buttle, 1996, p. 8). The SERVQUAL method, which represents five dimensions of service quality (tangibles, reliability, responsiveness, assurance, and empathy), is mentioned in the latest edition of the service marketing textbook (Wilson et al., 2021, pp. 89-91) and is well established in this field based on this fact. In the field of public administration, researchers have increasingly been using SERVQUAL methods (Afroj et al., 2021; Ocampo et.al. 2019; Bente, 2014; Wisniewski, 2001). Many studies have focused on satisfaction of citizens and customers various countries (Akinboade et al., 2012; Mansor 
\& Razali, 2010; Rhee \& Rha, 2009; Agus et al., 2007; Cripps et al., 2004; Huque \& Hayllar, 1999). This study referred to the framework used by Mansor and Razali (2010) in Malaysia. The present study uses the questionnaire in Moteki (2020), in which specific question items were grouped into three categories, originally developed by Mansor and Razali (2010). Mansor and Razali (2010) provide groupings and a broad description of each, but do not provide details within the paper of the specific questions for each group or how the survey was conducted.

Before the advent of SERVQUAL, Oliver's prominent study, focusing on the discrepancy between expectations and subsequent perceptions of performance as a determinant of customer satisfaction (Oliver, 1980; Oliver \& Winer, 1987), influenced later research on customer satisfaction. He published a book titled Satisfaction in 2010 (the second edition was Oliver, 2015). Many studies have been conducted in the field of public administration based on this expectancy-disconfirmation idea (Grimmelikhuijsen and Porumbescu, 2017; James, 2009; 2011; Van Ryzin, 2004; 2006; 2013; Van Ryzin \& Immerwahr, 2007; Van Ryzin et al., 2004). There is a growing body of research examining the relationship between customer or citizen satisfaction and other policy variables. Bouckaert and Van de Walle (2003) examine the appropriateness of using citizen trust and user satisfaction as indicators measuring good governance, and conclude that it is appropriate to include citizen trust, rather than user satisfaction, as a soft indicator for this purpose. Using a general mass survey of Norwegian citizens conducted in 2001, Christensen and Lægreid (2005) clarified several points concerning trust in government, including that citizens who were satisfied with public services tended to have trust in public institutions. Heintzman and Marson (2005) similarly assume that citizen trust and confidence in public institutions are generated by citizen/client service satisfaction. They argue that service satisfaction, employee satisfaction, and commitment are mutually influential, as shown in Figure 1, which shows the public-sector service value chain. Korunka et al. (2007), using their own scale of customer orientation through long-term questionnaire surveys in Australia and the United States, showed that customer orientation among employees is essential for customer satisfaction. Mouwen (2015) used data for 2010-2011 in the Netherlands on public transportation, including buses, subways, trams, and ferries, to examine whether user satisfaction is affected by the characteristics of the transportation mode and/or the attributes of the users.

\section{Methods}

To examine the determinants of satisfaction with administrative counter service, we prepared a questionnaire that can be divided into three groups with respect to the explanatory variables. The questionnaire comprised three main categories: physical aspects of facility equipment, counter staff responses, conditions of service delivery. The classification was based on the three explanatory categories used by Mansor and Razali (2010). There were ten survey questions and two screening questions concerning respondents' conformity to the survey conditions. Table 1 illustrates the main question items regarding counter service satisfaction in government offices, classified into the three concept groups. The questionnaire also asked for responses to items on individual personality and characteristics-(M) thoughts about management aspects of public administration, (I) international tendency, and $(F)$ authoritarian tendency-and posed a final open-ended question regarding how to 
improve ward offices. The name of question group $\mathrm{F}$ was drawn from the scale of authoritarianism presented by Adorno et.al. (1950), which is called the F Scale. These three additional sets of questions were used for exploratory analysis, to inform more detailed future studies. It has been pointed out that there is a connection between the NPM management orientation and authoritarianism and populism (Massey, 2019; Harun et al., 2021). In other words, the NPM management orientation is consistent with the authoritarian orientation among people and the populist tendencies in democracy, according to Massey (2019) and Harun et al. (2021). As a measure of authoritarian personality, Yonamine (1960) translated Adorno et al.'s (1950) questionnaire into Japanese and implemented it in Okinawa Prefecture. Some questions in that questionnaire were used in this study. For the questions on international orientation (I), the author used items from the psychological scale of Yashima (2002). As for privatesector management orientation (M), which states that the government should be run like a private company, the author developed original questions to investigate this.

Online surveys were distributed to residents in the 23 special wards of the Tokyo Metropolitan Area through Rakuten Insight, an online survey company. Members of Rakuten Insight's general survey panel agreed with the Monitor Agreement and Privacy Policy. These terms and conditions are posted on the company's website and are available for public review. The company has a system to protect personal information when conducting surveys and holds Privacy Mark Certification from the JIPDEC foundation. Prior to the screening questions regarding respondents' attributes, the following information was clearly displayed on the screen: (1) the author was responsible for carrying out the survey and was willing to answer questions about it (including questions about the results of the survey, to be published in academic journals), through a web form, and (2) the survey participation was voluntary and was not related to the city government; respondents would not be judged unfavorably based on their survey responses, and an explanation of the privacy protection policies and terms was provided at the beginning of this online survey. 
Table 1

Outline of survey basic question items

\section{Concept Groups}

A) Office hardware (buildings, tables, chairs, lighting, other)

B) Software (staff responses)

C) Service delivery

Y) Degree of customer satisfaction with counter services at the ward office

\section{Question Items}

AQ1 (Q4_1) Location (access from home)

AQ2 (Q4_2) Tables and chairs in the building

AQ3 (Q4_3) Indoor atmosphere

AQ4 (Q4_4) Ease of understanding the layout of the floors and offices inside the building

AQ5 (Q4_5) Ease of understanding the building's locations and entrances at the site of the ward office

AQ6 (Q4_6) Countermeasures against COVID-19 infection in buildings (partitions, sanitizer at entrances, etc.)

BQ1 (Q4_7) Courteousness of the counter staff

BQ2 (Q4_8) Ease of consultation and asking the counter staff questions

BQ3 (Q4_9) Ease of understanding oral explanations from the counter staff (speed)

BQ4 (Q4_10) Ease of understanding oral explanations from the counter staff (content)

CQ1 (Q5_1) Planned business in the ward office was completed after this visit

CQ2 (Q5_2) Length of time required to complete customer requests is short

CQ3 (Q5_3) The problem was solved after this visit to the ward office

CQ4 (Q5_4) The worries and my concerns were alleviated after this visit to the ward office

CQ5 (Q5_5) This time, I was able to run my errands at the ward office more smoothly than expected

YQ1 (Q6_1) Satisfaction with the experience at the ward office this time

YQ2 (Q6_2) I want to tell people about this experience at the ward office and how good it was

YQ3 (Q6_3) The administrative services provided by the ward office are convenient 
Table 2

Outline of survey question items concerning respondents' personality traits

\section{Concept Groups}

M) Introduction of privatesector management in public administration

\section{Question Items}

MQ1 (Q8_1) Public administration has different characteristics from the private sector, and there are differences in the way it operates.

MQ2 (Q8_2) There should be more people from the private sector in public administration management positions (department heads, section heads, etc.).

MQ3 (Q8_3) Administrative services such as water supply should be privatized as much as possible.

I) International orientation

IQ1 (Q9_1) I have a lot of things I want to talk about with people around the world.

IQ2 (Q9_2) I want to avoid jobs that require a lot of overseas business trips. $\left({ }^{*}\right)$

IQ3 (Q9_3) I often watch and read news about foreign countries.

F) Authoritarian orientation

FQ1 (Q9_4) When you are young, you may be rebellious, but you must have a moderate personality

FQ2 (Q9_5) Respecting your superiors and listening to them is the most important thing for children to learn.

FQ3 (Q9_6) It is only through strenuous efforts that anyone can learn what is truly important.

Note: The $\left({ }^{*}\right)$ marked item indicates reverse items.

\section{Results}

The survey was conducted on a weekday (December 1,2021). There were a total of 400 respondents: 162 $(40.5 \%)$ were in their 30s, 129 (32.3\%) in their 40s, and 109 (27.3\%) in their 50s (because of rounding, the total does not add up to $100.0 \%$ ). The collection time was just after the typical lunch break in Japan, from 13:03 to 14:20, a little over an hour, until the planned number of respondents was gathered. Table 3 shows the respondents' reasons for visiting the ward office (they were asked to choose only one). This shows that the largest percentage of residents visited the ward office for matters related to family registration or resident registration. 
Table 3

Which of the following is the main business you visited the ward office for this time?

\begin{tabular}{|clccc|}
\hline & & $\mathbf{n}$ & $\%$ \\
\hline 1 & Total & 400 & 100.0 \\
& $\begin{array}{l}\text { Matters related to notification of family register, resident registration, issuance of } \\
\text { resident certificate, indication of address, and seal registration }\end{array}$ & 113 & 28.3 \\
\hline 2 & Matters related to my number (social security number) & 71 & 17.8 \\
\hline 3 & Garbage, pollution, and dog registration & 3 & 0.8 \\
\hline 4 & Tax, fee payment, and elections & 48 & 12.0 \\
\hline 5 & $\begin{array}{l}\text { Matters related to national health insurance, national pension, nursing care } \\
\text { insurance, disability certificate, child care, and medical care (welfare and health) }\end{array}$ & 89 & 22.3 \\
\hline 6 & Others & 76 & 19.0 \\
\hline
\end{tabular}

First, a factor analysis is conducted to check whether the grouping of the three groups of explanatory variables, $A$ through $C$, is appropriate. This method of confirming the appropriateness of the grouping of the questionnaire by factor analysis was informed by Kawasaki et.al. (2014), Takahashi and Kawasaki (2019), and Takahashi (2020). Using the same set of questions as SERVQUAL, Talib and Shukor (2016) conducted a factor analysis for each question and found that it was appropriate to divide the questionnaire into three groups. Using question items $\mathrm{A}-\mathrm{C}$, the maximum likelihood method was used for factoring, and the Varimax method was used for factor rotation. The eigenvalues were, in order from the first factor, 7.732, 1.992, 1.229, and 0.796. Up to the third factor, the eigenvalue is greater than or equal to 1 (the Kaiser-Guttman criterion). The number of factors was determined to be 3 according to both the Kaiser-Guttman criterion and the scree plot criterion. The scree plot of Figure 2 shows that the third factor is valid. Looking at the results of the factor analysis in Table 4, the three classifications based on the factor scores of each question item are basically consistent with the three classifications assumed by the author. For Q4_6, regarding infection control measures such as sanitizing solutions and acrylic plates for COVID-19, factor scores calculated from factor analysis exceeded 0.4 for the first and second factors. This means that question Q4_6 is an item that relates to both Factor 1 and Factor 2 (Group A and B in the author's questionnaire classification). What this means is that infection control measures such as sanitizing solutions and acrylic panels for COVID-19 involve questions about hardware as well as the nature of the responses by staff; infectious diseases can be passed from person to person, and staff members sometimes talk to each other about sanitizing. In addition, both government agencies and private establishments often have problems regarding disinfection and saliva spray, and such recent circumstances during the pandemic may be reflected in this. 
Table 4

Results of Factor Analysis

\begin{tabular}{|llll|}
\hline & Factor 1 & Factor 2 & Factor 3 \\
\hline Q4.4 & 0.914 & \\
\hline Q4.5 & 0.888 & \\
\hline Q4.3 & 0.729 & \\
\hline Q4.2 & 0.620 & \\
\hline Q4.6 & 0.567 & 0.483 & \\
\hline Q4.1 & 0.401 & & \\
\hline Q4.9 & & 0.866 & \\
\hline Q4.8 & & 0.837 & \\
\hline Q4.10 & & 0.836 & 0.851 \\
\hline Q4.7 & & 0.778 & 0.757 \\
\hline Q5.3 & & & 0.674 \\
\hline Q5.1 & & & 0.576 \\
\hline Q5.4 & & & 0.451 \\
\hline Q5.5 & & & \\
\hline Q5.2 & & & \\
\hline contribution rate & & \\
\hline Note: Only factor scores of 0.4 or higher are given numerical values in the table. \\
\hline
\end{tabular}

As shown in Table 5, the correlation coefficient between the second and third factors is .060 , but this and the other correlation coefficients between different factors in this table are not significant at the $5 \%$ level. From this, we can assume that each factor is independent. The results of the factor analysis so far are similar to those of Talib and Shukor (2016), indicating that the grouping of three groups is appropriate in terms of content homogeneity across questions, less than SERVQUAL's five groups. 
Table 5

factor correlation matrix

\begin{tabular}{|llll|}
\hline & Factor 1 & Factor 2 & Factor 3 \\
\hline Factor 1 & 1 & 0.039 & 0.014 \\
\hline Factor 2 & 1 & 0.060 \\
\hline Factor 3 & & & 1 \\
\hline
\end{tabular}

Next, a principal component regression analysis was performed using the three groups of questions (main items), whose grouping had been confirmed as appropriate by the factor analysis. First, the principal component analysis for each question in category $Y$ was conducted (Figure 3). The figure shows the positioning of the three questions on overall satisfaction ( $Y$ category) with respect to the first and second components from the results of the principal component analysis. For variable naming, $\mathrm{Z}$ is used at the beginning of the variable name for the principal component score variable; $Y$ derives its name from the $Y$ group of the objective variable. The new variables $Z Y 1$ and $Z Y 2$ from the principal component scores were added to the dataset. YQ1, YQ2, and YQ3 experienced a similar trend for Component 1. YQ3 (Q6_3) has a marginally higher value for component 1, interpreted as "delivered service convenience"; YQ2 (Q6_2) and YQ3 exhibit a similar trend concerning the second principal component, interpreted as "long-term/short-term satisfaction."

Table 6 shows the correlation coefficients between each question item in groups A to C and ZY1. The following principal components analysis for each group uses the marked question items, with a correlation coefficient of 0.4 or higher. However, for groups I, $\mathrm{M}$, and $\mathrm{A}$, which are additional questions, all question items are used as they are for the principal component analysis, because the structure and content of the questions for each of the three scales have not yet been fully explored and will be used for exploratory purposes only (the results of the correlation analysis with ZY1 are shown in Table 7). 
Table 6

Co-relationship between component ZY1 and the basic question items

\begin{tabular}{|c|c|}
\hline Question Items & $r$ \\
\hline AQ1 (Q4_1) & $0.288 * \star$ \\
\hline AQ2 (Q4_2)* & $0.489 * \star$ \\
\hline AQ3 (Q4_3)* & $0.532^{\star \star}$ \\
\hline AQ4 (Q4_4)* & $0.472^{\star \star}$ \\
\hline AQ5 (Q4_5)* & $0.489 * \star$ \\
\hline AQ6 (Q4_6)* & $0.532^{\star \star}$ \\
\hline BQ1 (Q4_7)* & $0.650 * \star$ \\
\hline BQ2 (Q4_8)* & $0.679 * *$ \\
\hline BQ3 (Q4_9)* & $0.687 * \star$ \\
\hline BQ4 (Q4_10)* & $0.703^{\star \star}$ \\
\hline CQ1 (Q5_1)* & $0.503^{\star *}$ \\
\hline CQ2 (Q5_2)* & $0.603^{\star *}$ \\
\hline CQ3 (Q5_3)* & $0.511^{\star *}$ \\
\hline CQ4 (Q5_4)* & $0.585^{\star \star}$ \\
\hline CQ5 (Q5_5)* & $0.717^{\star \star}$ \\
\hline \multicolumn{2}{|c|}{$\begin{array}{l}\text { * Questionnaire items with correlation coefficients of } 0.4 \text { or higher were used in the principal } \\
\text { component analysis for each category. }\end{array}$} \\
\hline$\star \star p<.01$ & \\
\hline
\end{tabular}


Table 7

Co-relationship between component ZY1 and the question items concerning respondents' personality traits

\begin{tabular}{|ll|}
\hline MQ1 (Q8_1) & $0.172^{\star \star}$ \\
\hline MQ2 (Q8_2) & $0.140^{\star \star}$ \\
\hline MQ3 (Q8_3) & 0.018 \\
\hline IQ1 (Q9_1) & $0.178^{\star \star}$ \\
\hline IQ2 (Q9_2) & 0.046 \\
\hline IQ3 (Q9_3) & $0.142^{\star \star}$ \\
\hline FQ1 (Q9_4) & $0.175^{\star \star}$ \\
\hline FQ1 (Q9_5) & $0.162^{\star \star}$ \\
\hline FQ3 (Q9_6) & $0.171^{\star \star}$ \\
\hline ** $p<.01$. & \\
\hline $\begin{array}{l}\text { Note: The p-values for all these questions were below } 0.4 . \text { In the principal component analysis, those } \\
\text { that are significant at the 1\% level will be used. }\end{array}$ \\
\hline
\end{tabular}

Principal component analysis was conducted for each group (A-C) using the selected question items, and composite variables for explanatory variables used later in the regression analysis were created. Principal component analysis was conducted for each question in category A (Figure 4), and the scores for the first and second components were added to the dataset as variables ZA1 and ZA2, respectively. The point slightly above Q4_5, where the caption disappears owing to the drawing of the figure, is Q4_4. As shown, AQ3 (Q4_3) has one of the most significant effects on the first principal component. Q4_4 and Q4_5 are also located on the right side of the figure. Based on these points, component 1 can be interpreted as "Atmosphere in the building, ease of finding the location in general." Q4_2 is about office furniture such as desks and chairs in the building, and Q4_3 is about the physical atmosphere of the facility equipment in the building. Component 2 can be interpreted as the "office furniture" if looking at the position of AQ2 (Q4_2).

The results of the principal component analysis for each question in category $B$ are shown in Figure 5 . New variables ZB1 and ZB2, calculated from principal component scores, were added to the dataset. Figure 5 shows that BQ1 (Q4_7) to BQ4 (Q4_10) had almost the same significant effects on component 1 (ZB1), which was interpreted as "Ease of consultation with the counter staff and clarity of explanations in general." Component 2 (ZB2) can be interpreted as "Ease of asking questions of the counter staff /ease of understanding oral explanations" if focusing on the combination of Q4_7-Q4_8 and Q4_9-Q4_10. Both Q4_9 and Q4_10 are related to the ease of understanding oral explanations by the counter staff.

Figure 6 presents the results of PCA for each question in category C. As indicated, the scores for the first and second components were added to the dataset as variables ZC1 and ZC2. Q5_3 and Q5_5 are 
located at right in the figure. The other variables are also positive for the first principal component, and they are all positioned on the right side. Component 1 can be interpreted as "Solving customer problems and concerns"; then, if focusing on the position of CQ2 (Q5_2) and Q5_5, both of which are concerning time for work and processing, component 2 can be interpreted as "Service promptness at the ward office."

Figures 7 to 9 show the configuration map of the principal component analysis conducted for each of the $\mathrm{M}, \mathrm{I}$, and $\mathrm{F}$ question groups related to the respondents' personalities and thoughts. The first and second principal components of each were added to the dataset and included the variables ZM1, ZM2, ZI1, ZI2, $\mathrm{ZF1}$, and ZF2.

First, as in the author's previous similar studies, multiple regression analysis was conducted using the principal component scores of the three groups $\mathrm{A}-\mathrm{C}$. The results of multiple regression analysis on ZY1, using the variable increasing and decreasing method with synthetic variables generated from the categories of explanatory variable questions (ZA1, ZA2, ZB1, ZB2, ZC1, and ZC2), are displayed in Table 8. The adjusted R-squared value of the model's coefficient of determination is .69, which is the highest compared with the authors' previous studies. The standardized partial regression coefficients of ZC1 were the highest at .50 (significant at the 1\% level). Thus, ZC1 was the most important variable for the explained variable (ZY1). When comparing the first principal components, the first component of $B$ (customer service provided by staff) and the first component of $A$ (office hardware) follow, in that order. The variance inflation factor (VIF) of ZB1 was slightly greater than 2.00. This means that there is an overlap between the set explanatory variables (i.e., the risk of multicollinearity) in group $B$.

Table 8

Multiple regression predicting overall customer satisfaction (component ZY1): Model 1

\begin{tabular}{|lllll|}
\hline & Zero-order $\boldsymbol{R}$ & $\boldsymbol{B}$ & $\boldsymbol{P}$ & VIF \\
\hline ZA1 & $.557^{\star \star}$ & $.13^{\star \star}$ & .0002 & 1.64 \\
\hline ZB1 & $.710^{\star \star}$ & $.32^{\star \star}$ & $<.0001$ & 2.05 \\
\hline ZC1 & $.739 \star \star$ & $.50^{\star \star}$ & $<.0001$ & 1.52 \\
\hline ZC2 & $.192^{\star \star}$ & $.12^{\star \star}$ & $<.0001$ & 1.04 \\
\hline Note: $R^{2}=.70$; Adjusted $R^{2}=.69 ;$ \\
\hline \multirow{2}{*}{$p<.01$} \\
\hline
\end{tabular}

Next, multiple regression analysis (Model 2) was conducted by adding the principal component scores of the variables related to the personalities and thoughts of the users $(\mathrm{M}, \mathrm{I}$, and $\mathrm{F})$ in addition to the explanatory variables of the three groups $(A-C)$. Table 9 shows the results of the regression analysis in Model 2. The adjusted R-squared value of the model's coefficient of determination is .71, which is higher than that of Model 1. At the 1\% level, ZC1 and ZA1 had positive effects on the explained variable ZY1, in that order. The VIF for VB1 was slightly over 2.00; therefore, some concerns remain regarding 
independence among the selected explanatory variables. The principal component score variables calculated from the I and F groups (ZI1, ZI2, and ZF2) had coefficients that were significant at the $1 \%$ level in this model. The first principal component of group I (international orientation) had a positive coefficient, the second principal component had a negative coefficient, and the standardized partial regression coefficient $(B)$ was small but statistically significant. Because the adjusted R-squared value of the model's coefficient of determination is higher than that of Model 1, we can say that Model 2, with the respondent's personality and thoughts variables, has more explanatory power than Model 1.

Table 9

Multiple regression predicting overall customer satisfaction: Model 2 (including users' personality traits $\mathrm{M}, \mathrm{l}$, and $\mathrm{F}$ )

\begin{tabular}{|c|c|c|c|c|}
\hline & Zero-order $R$ & $B$ & $P$ & VIF \\
\hline ZA1 & $.557 \star \star$ & $.11^{\star \star}$ & .0017 & 1.69 \\
\hline ZB1 & $.710 * \star$ & $.32^{\star}$ & $<.0001$ & 2.10 \\
\hline ZC1 & $.739 * \star$ & $.51^{\star \star}$ & $<.0001$ & 1.55 \\
\hline ZC2 & $.197 \star \star$ & $.12^{\star \star}$ & $<.0001$ & 1.05 \\
\hline ZM1 & $.175^{\star \star}$ & -.04 & .2253 & 1.25 \\
\hline ZM2 & .035 & .04 & .1364 & 1.01 \\
\hline ZI1 & $.182^{\star *}$ & $.08^{\star \star}$ & .0074 & 1.15 \\
\hline $\mathrm{ZI2}$ & -.038 & $-.12^{\star \star}$ & $<.0001$ & 1.05 \\
\hline ZF1 & $.204^{\star \star}$ & $.08^{\star \star}$ & .0043 & 1.12 \\
\hline \multicolumn{5}{|c|}{ Note: $R^{2}=.72 ;$ Adjusted $R^{2}=.72$; } \\
\hline \multicolumn{5}{|c|}{$\star * p<.01 * p<.05$} \\
\hline
\end{tabular}

\section{Discussion}

The results of this survey of Tokyo ward office users were consistent with the results of the author's surveys conducted at Osaka City Ward Office and Higashihiroshima City Hall (Moteki, 2021). This study conducted an online survey targeting female customers of ward offices in the Tokyo Metropolitan Area government. As in previous surveys, a two-step statistical analysis was conducted, comprising principal component analysis and multiple regression analysis. The main question items as explanatory variables for the analysis were presented in three specific categories: $A, B$, and C. Multiple regression analysis used two principal components calculated from each category. The regression analysis (Table 3 ) demonstrated that ZC1 from group $C$ (service delivery) was the most influential $(\beta=.50)$, followed by ZB1 (the first component of customer service provided by the counter staff) and ZA1 (the first component of 
office hardware), with an adjusted R2 value of .70. For explanatory variables $\mathrm{A}-\mathrm{C}$, the most influential variable was $\mathrm{ZC1}$. The regression coefficients for each variable indicated that the most important variable was service delivery quality (group C). This result was inconsistent with the results of Mansor and Razali (2010) in Malaysia, which revealed that the human factor was more important than administrative services themselves. Our study results of the 2020 survey at the Kurose branch office of Higashihiroshima City government similarly showed that the human factor was the most influential, and the results differed from the results of this survey of ward office users in Tokyo and Osaka. This difference would indicate the regional factors of urban and rural areas and the different authorities that government offices have. In this pandemic era of widespread coronavirus infections, both private and public organizations are increasingly required to improve their service delivery methods and service quality (Sheth, 2020). In future research, I would like to examine how the changes brought about by COVID 19, including the infection prevention measures in the facilities discussed in this paper, affect the factors that contribute to customer satisfaction, or the factors that improve service quality, and the psychological conditions and behavior of users and employees in the facilities.

In this study, we additionally asked three groups of questions (I, M, and F) related to the respondents' personality and thoughts, which were used in the multivariate analysis. For the first time, a confirmatory factor analysis was conducted to examine the appropriateness of the grouping of explanatory variables. In light of criteria consisting of eigenvalues and the Kaiser-Guttman criterion, three categories were found to be appropriate, as expected. Thus, we wrapped up each of them as a compound variable through principal component analysis and analyzed their correlation with the explanatory variable ZY1. Next, we conducted a multiple regression analysis of customer satisfaction, taking into account the personality and thoughts of the facility users, and were able to construct a model with more explanatory power in terms of the coefficient of determination (Model 2: Adjusted $R^{2} .72$ ) than when analyzing only the variables of the administrative side involved in the service (Model 1). As mentioned in the introduction and the related research section, factors that contribute to customer satisfaction are not only the quality of the services provided, but also the circumstances and attributes of the users themselves and the service providers or the counter staff. Looking at the results of the regression analysis as described here, especially the statistical significance of its coefficient of determination and standardized partial regression coefficients, it can be understood that it is possible to use the service quality evaluation method widely applied in the private sector, such as that attempted in this study, in the public sector. Differences between public and private organizations include the strength of regulation by law and the ambiguity of goals (Rainey, 2010). In the future, we would like to consider and explore more appropriate and effective methods of surveying service quality, focusing on the characteristics of public organizations. In addition, perspectives on employee satisfaction are beneficial in exploring the conditions of customer satisfaction in government offices. In public administration, human factors have a significant effect on customer satisfaction.

This study set three main categories: hardware, counter officer responses, and service delivery quality (groups A-C). Additional aspects related to other customer satisfaction factors may be needed for future 
research, to develop a more explanatory model. Items with less than 0.4 correlation coefficients with the composite variables $Y$ group were not subjected to principal component analysis. To explore models and questionnaires that can better grasp customer satisfaction at government offices, we need to conduct a follow-up survey with renewed and refined question items. By comparing the results of these surveys with those of such future studies, the determinants of customer satisfaction could then be explored in detail.

The author conducted two on-site surveys in government buildings and three Internet surveys on customer satisfaction in public administration in Japan. On-site and Internet surveys each have advantages and disadvantages. The advantages of the on-site survey are that (1) the researcher can answer respondents questions about the questionnaire directly and (2) the researcher can check the actual situation of the government office during the survey period and identify unexpected events such as angry users. Internet surveys also have their merits, the most important being the ability to eliminate the time and effort involved in processing data, including data entry and tabulation. Another advantage is that, as shown in this paper, it is relatively easy to conduct surveys that include matters related to the respondent's personality and attributes, which are difficult to obtain in face-to-face surveys. Although we were unable to investigate this in detail in this analysis, the author would like to examine whether the mode of survey (on-site or Internet) has any effect on the results of the satisfaction survey.

The author conducted a quantitative survey in the field of Japanese local governments using a questionnaire consisting of three original groups of questions, which are simplified versions of the five groups of SERVQUAL. In this regard, there are ways to focus on the exceptional case of angry customers, as in Bougie et al. (2003). These people are called "claim" or "claimer" in Japanese language, with a negative meaning, and the problem of trouble between citizens and counter staff developing from customer complaints is becoming more and more prevalent at administrative offices in Japan. The troubles described here seem to be caused by various reasons, such as (1) long waiting time, (2) unfulfilled wishes, (3) original distrust that users have for government agencies, (4) users' dissatisfaction with society and government agencies, and (5) users' bad health conditions. One customer's problem can often affect the satisfaction of other customers and the motivation of the administrative staff, because the presence of an angry user on the floor will inspire anger and anxiety in other users. Service recovery, meaning recovery or resolution from a failure in service delivery that caused customer outrage or dissatisfaction. has begun to be discussed in business administration as a way to deal with customer complaints, customer service failures, and errors (Johnston and Michel, 2008). For the present kind of study, dealing with customer complaints and service recovery in public administration, a qualitative study involving detailed investigation of individual cases and individual interviews with staff and citizens would be useful. In addition to the quantitative methods using questionnaires that we have focused on so far, we would thus like to add qualitative methods, such as interviews, to further work on the study of customer satisfaction in public administration in Japanese settings.

\section{Declarations}

Competing interests: The author declares no competing interests. 
Funding: This work was supported by a subsidy for English editing services provided by the affiliated university.

\section{References}

1. Adorno, T. W., Frenkel-Brunswik, E., Levinson, D. J. \& Sanford, R. N. (1950). The authoritarian personality. The American Jewish Committee.

2. Afroj, S., Hanif, F., Hossain, M. B., Fuad, N., Islam, I., Sharmin, N., \& Siddiq, F. (2021). Assessing the municipal service quality of residential neighborhoods based on SERVQUAL, AHP and Citizen's Score Card: A case study of Dhaka North City Corporation area, Bangladesh. Journal of Urban Management. https://doi.org/10.1016/j.jum.2021.03.001

3. Agus, A., Barker, S., \& Kandampully, J. (2007). An exploratory study of service quality in the Malaysian public service sector. International Journal of Quality \& Reliability Management, 24(2), 177-190. https://doi.org/10.1108/02656710710722284

4. Akinboade, O. A., Kinfack, E. C., \& Mokwena, M. P. (2012). An analysis of citizen satisfaction with public service delivery in the Sedibeng district municipality of South Africa. International Journal of Social Economics, 39(3), 182-199. https://doi.org/10.1108/03068291211199350

5. Almqvist, R., Grossi, G., Van Helden, G. J., \& Reichard, C. (2013). Public sector governance and accountability. Critical Perspectives on Accounting, 24(7-8), 479-487. https://doi.org/10.1016/j.cpa.2012.11.005

6. Atreya, B., \& Armstrong, A. (2002). A review of the criticisms and the future of new public management. Working Paper Series of Victoria University of Technology. https://vuir.vu.edu.au/169/

7. Bente, F. M. (2014). Ethnicity and Citizen Satisfaction: A Study on Local Public Administration. Procedia Economics and Finance, 15, 1324-1330. https://doi.org/10.1016/S2212-5671(14)00595-4

8. Bouckaert, G., \& Van de Walle, S. (2003). Comparing measures of citizen trust and user satisfaction as indicators of "good governance": Difficulties in linking trust and satisfaction indicators. International Review of Administrative Sciences, 69(3), 329-343. https://doi.org/10.1177/0020852303693003

9. Box, R. C. (1999). Running government like a business: Implications for public administration theory and practice. The American Review of Public Administration, 29(1), 19-43. https://doi.org/10.1177\%2F02750749922064256

10. Brown, T. (2007). Coercion versus choice: Citizen evaluations of public service quality across methods of consumption. Public Administration Review, 67(3), 559-572. https://doi.org/10.1111/j.1540-6210.2007.00737.x

11. Bougie, R., Pieters, R., \& Zeelenberg, M. (2003). Angry customers don't come back, they get back: The experience and behavioral implications of anger and dissatisfaction in services. Journal of the Academy of Marketing Science, 31(4), 377-393. https://doi.org/10.1177\%2F0092070303254412 
12. Brunet, M., \& Aubry, M. (2016). The three dimensions of a governance framework for major public projects. International Journal of Project Management, 34(8), 1596-1607.

https://doi.org/10.1016/j.ijproman.2016.09.004

13. Buttle, F. (1996). SERVQUAL: Review, critique, research agenda. European Journal of Marketing, 30(1), 8-32. https://doi.org/10.1108/03090569610105762

14. Christensen, T., \& Lægreid, P. (2005). Trust in government: The relative importance of service satisfaction, political factors, and demography. Public Performance \& Management Review, 28(4), 487-511. https://www.tandfonline.com/doi/pdf/10.1080/15309576.2005.11051848

15. Campbell, C., \& Peters, B. G. (1988). The politics/administration dichotomy: Death or merely change? Governance, 1(1), 79-99. https://doi.org/10.1111/j.1468-0491.1988.tb00060.x

16. Compton, M., Douglas, S., Fahy, L., Luetjens, J., 't Hart, P., \& Van Erp, J. (2021). New development: Walk on the bright side-what might we learn about public governance by studying its achievements? Public Money \& Management, 1-3. https://doi.org/10.1080/09540962.2021.1975994

17. Cripps, H., Ewing, M., \& McMahon, L. (2004). Customer satisfaction in local government: The case of the restructured city of Perth, Australia. Journal of Nonprofit and Public Sector Marketing, 12(1), 122. https://doi.org/10.1300/J054v12n01_01

18. Deb, S., \& Ahmed, M. A. (2018). Determining the service quality of the city bus service based on users' perceptions and expectations. Travel Behaviour and Society, 12, 1-10. https://doi.org/10.1016/j.tbs.2018.02.008

19. Denhardt, J. V., \& Denhardt, R. B. (2015). The new public service: Serving, not steering. Routledge.

20. Dickson, H. (2016). From New Public Management to New Public Governance: The implications for 'new public service'. In J. Butcher and D. Gilchrist (Eds.), The Three Sector Solution: Delivering public policy in collaboration with not-for-profits and business, 41-60, ANU Press.

21. Everitt, B. S. (2005). An R and S-PLUS companion to multivariate analysis. Springer Science \& Business Media.

22. Grimmelikhuijsen, S., \& Porumbescu, G. A. (2017). Reconsidering the expectancy disconfirmation model. Three experimental replications. Public Management Review, 19(9), 1272-1292. https://doi.org/10.1080/14719037.2017.1282000

23. Harun, H., Graham, P., Kamase, H. P., \& Mir, M. (2021). A critical analysis of the impacts of financial literacy and NPM on Village Funds Initiative in Indonesia. International Journal of Public Administration, 44(4), 336-345. https://doi.org/10.1080/01900692.2020.1722165

24. Haywood-Farmer, J. (1988). A conceptual model of service quality. International Journal of Operations \& Production Management, 8(6), 19-29. https://doi.org/10.1108/eb054839

25. Heintzman, R., \& Marson, B. (2005). People, service and trust: is there a public sector service value chain? International Review of Administrative Sciences, 71(4), 549-575. https://doi.org/10.1177/0020852305059599 
26. Huque, A. S., \& Hayllar, M. R. (1999). The limits of customer satisfaction: The case of the Companies Registry Trading Fund in Hong Kong. Asian Review of Public Administration, 11(2), 100-113. https://citeseerx.ist.psu.edu/viewdoc/download?doi=10.1.1.1067.3965\&rep=rep1\&type=pdf

27. James, O. (2011). Managing citizens' Expectations of public service performance: Evidence from observation and experiment in local government. Public Administration, 89(4), 1419-1435.

28. James, O. (2009). Evaluating the expectations disconfirmation and expectations anchoring approaches to citizen satisfaction with local public services. Journal of Public Administration Research and Theory, 19(1), 107-123. https://doi.org/10.1093/jopart/mum034

29. Johnson, J. L. (1999). Strategic integration in industrial distribution channels: Managing the interfirm relationship as a strategic asset. Journal of Academy of Marketing Science, 27(1), 4-18. https://doi.org/10.1177\%2F0092070399271001

30. Johnston, R., \& Michel, S. (2008). Three outcomes of service recovery: Customer recovery, process recovery and employee recovery. International Journal of Operations \& Production Management. https://doi.org/10.1108/01443570810841112

31. Kawasaki, S., Takahashi, T., \& Suzuki, K. (2014). The effect of autonomous career actions on selfcareer formation from the viewpoint of quality management. Proceedings of International Conference on Quality '14, Tokyo, 152-163.

32. Korunka, C., Scharitzer, D., Carayon, P., Hoonakker, P., Sonnek, A., \& Sainfort, F. (2007). Customer orientation among employees in public administration: A transnational, longitudinal study. Applied Ergonomics, 38(3), 307-315. https://doi.org/10.1016/j.apergo.2006.04.019

33. Mansor, N., \& Razali, CHCM (2010). Customers' satisfaction towards counter service of local authority in Terengganu, Malaysia. Asian Social Science, 6(8), 197. https://doi.org/10.5539/ass.v6n8p197

34. Massey, A. (2019). Persistent public management reform: an egregore of liberal authoritarianism? Public Money \& Management, 39(1), 9-17. https://doi.org/10.1080/09540962.2018.1448160

35. Moteki, Y. (2021). Customer satisfaction with services at the ward offices of Osaka City Government. Journal of Urban Management and Local Government Research, 36(1), 91-103.

36. Moteki, Y. (2020). A Questionnaire Survey on Customer Satisfaction with Services at Branch Offices of Higashihiroshima City in Hiroshima Prefecture: Focusing on office hardware, customer service provided by Counter Officers, and Service Delivery Quality. Advance. Preprint. https://doi.org/10.31124/advance.13072997.v1

37. Mouwen, A. (2015). Drivers of customer satisfaction with public transport services. Transportation Research Part A: Policy and Practice, 78, 1-20. http://dx.doi.org/10.1016/j.tra.2015.05.005

38. Nazi, K. M. (2010). Veterans' voices: use of the American Customer Satisfaction Index (ACSI) Survey to identify My HealtheVet personal health record users' characteristics, needs, and preferences. Journal of the American Medical Informatics Association, 17(2), 203-211. https://doi.org/10.1136/jamia.2009.000240 
39. Noda, Y. (2021). Performance information and learning effects on citizen satisfaction with public services. Public Management Review, 23(12), 1833-1855.

https://doi.org/10.1080/14719037.2020.1775281

40. Noda Y. (2019). Citizen expectations and satisfaction of service performance: Lessons from subnational governments in Japan. Asia Pacific Journal of Public Administration, 41(3), 142-156. https://doi.org/10.1080/23276665.2019.1658361

41. Noda, Y. (2014). Nonlinear effects on citizen satisfaction and different levels of governments in Japan. Asian Review of Public Administration, 25(1), 74-91. https://doi.org/10.1007/978-3-31931816-5_3265-1

42. Noda, Y. (2013). Shimin manzoku-do no kenkyū [Research on citizen satisfaction]. Nippon Hyoronsha.

43. Ocampo, L., Alinsub, J., Casul, R. A., Enquig, G., Luar, M., Panuncillon, N., ... Ocampo, C. O. (2019). Public service quality evaluation with SERVQUAL and AHP-TOPSIS: A case of Philippine government agencies. Socio-Economic Planning Sciences, 68, 100604.

https://doi.org/10.1016/j.seps.2017.12.002

44. Oliver, R. L. (2015). Satisfaction: A behavioral perspective on the consumer (2nd ed.). Routledge.

45. Oliver, R. L. (1980). A cognitive model of the antecedents and consequences of satisfaction decisions. Journal of Marketing Research, 17(4), 460-469. https://doi.org/10.1177\%2F002224378001700405

46. Oliver, R. L., \& Winer, R. S. (1987). A framework for the formation and structure of consumer expectations: Review and propositions. Journal of Economic Psychology, 8(4), 469-499. https://doi.org/10.1016/0167-4870(87)90037-7

47. Osborne, S. P. (2006). The new public governance? Public Management Review, 8(3), 377-387. https://doi.org/10.1080/14719030600853022

48. Parasuraman, A., Zeithaml, V. A., \& Berry, L. L. (1985). A conceptual model of service quality and its implications for future research. Journal of Marketing, 49(4), 41-50.

https://doi.org/10.1177\%2F002224298504900403

49. Public Interest Incorporated Foundation Special Wards Council. (2019). Tokubetsu-ku to wa [What is a special ward?]. https://www.tokyo-23city.or.jp/chosa/tokubetsuku/whats.html

50. Rainey, H. G. (2010). Goal ambiguity and the study of American bureaucracy. In Durant, R. F. (Ed.). (2012). The Oxford handbook of American bureaucracy. Oxford University Press.

51. Rha, J. Y. (2012). Customer satisfaction and qualities in public service: an intermediary customer perspective. The Service Industries Journal, 32(12), 1883-1900.

https://doi.org/10.1080/02642069.2011.574274

52. Rhee, S. K., \& Rha, J. Y. (2009). Public service quality and customer satisfaction: Exploring the attributes of service quality in the public sector. The Service Industries Journal, 29(11), 1491-1512. https://doi.org/10.1080/02642060902793441 
53. Sam, E. F., Hamidu, O., \& Daniels, S. (2018). SERVQUAL analysis of public bus transport services in Kumasi metropolis, Ghana: Core user perspectives. Case studies on transport policy, 6(1), 25-31. https://doi.org/10.1016/j.cstp.2017.12.004

54. Sheth, J. (2020). Business of business is more than business: Managing during the Covid crisis. Industrial Marketing Management, 88, 261-264. https://doi.org/10.1016/j.indmarman.2020.05.028

55. Singh, G., \& Slack, N. J. (2020). New Public Management and customer perceptions of service quality -a mixed-methods study. International Journal of Public Administration.

https://doi.org/10.1080/01900692.2020.1839494

56. Smith, T. A. (2020). The role of customer personality in satisfaction, attitude-to-brand and loyalty in mobile services. Spanish Journal of Marketing. http://dx.doi.org/10.1108/SJME-06-2019-0036

57. Swallehe, O. (2021). Service delivery and customer satisfaction in public organizations. IUP Journal of Marketing Management, 20(2), 7-33.

58. Takahashi, T. (2020) Shitsumon-su no ooi anketo chosa no tame no ryogawa inga bunseki [Dualsided causal analysis for questionnaire survey with large number of questions about cause and result]. Paper presented at the Discovery Summit, Japan, held on November 17, 2020.

59. Takahashi, T., \& Kawasaki, M. (2019). Anketo ni yoru chosa to kaso jikken: Kokyakumanzoku-do no haaku to kojo [Survey and virtual experiments by questionnaire: Understanding and improving customer satisfaction]. Nikkagiren.

60. Talib, M. A., \& Shukor, N. J. A. (2016). Quality measurement of public payment counter service: A statistical approach. In M. A. Abdullah, W. K. Yahya, M. Ramli, S. R. Mohamed, \& B. E. Ahmad (Eds.), Regional Conference on Science, Technology and Social Sciences (RCSTSS 2014) (pp. 1053-1062). Springer.

61. Thomas, J. C. (2013). Citizen, customer, partner: Rethinking the place of the public in public management. Public Administration Review, 73(6), 786-796. https://doi.org/10.1111/puar.12109

62. Tokyo Metropolitan Government. (2020). Tokyo-to nenpyo [Chronological Table of Tokyo Metropolitan Government]. https://www.metro.tokyo.lg.jp/tosei/tokyoto/profile/gaiyo/nenpyo.html

63. Tokyo Metropolitan Government. (2018). Tokunai shichoson mappu [Map of wards, cities, towns and villages in Tokyo Metropolitan Government]. https://www.metro.tokyo.lg.jp/tosei/tokyoto/profile/gaiyo/kushichoson.html

64. Van Ryzin, G. G. (2013). An experimental test of the expectancy-disconfirmation theory of citizen satisfaction. Journal of Policy Analysis and Management, 32(3), 597-614. https://doi.org/10.1002/pam.21702

65. Van Ryzin, G. G. (2006). Testing the expectancy disconfirmation model of citizen satisfaction with local government. Journal of Public Administration Research and Theory, 16(4), 599-611. https://doi.org/10.1093/jopart/mui058

66. Van Ryzin, G. G. (2004). Expectations, performance, and citizen satisfaction with urban services. Journal of Policy Analysis and Management, 23(3), 433-448. https://doi.org/10.1002/pam.20020 
67. Van Ryzin, G. G., \& Immerwahr, S. (2007). Importance-performance analysis of citizen satisfaction surveys. Public Administration, 85(1), 215-226. https://doi.org/10.1111/j.1467-9299.2007.00641.x

68. Van Ryzin, G. G., Muzzio, D., Immerwahr, S., Gulick, L., \& Martinez, E. (2004). Drivers and consequences of citizen satisfaction: An application of the American customer satisfaction index model to New York City. Public Administration Review, 64(3), 331-341. https://doi.org/10.1111/j.1540-6210.2004.00377.x

69. Vermeeren, B., Kuipers, B., \& Steijn, B. (2011). Two faces of the satisfaction mirror: A study of work environment, job satisfaction, and customer satisfaction in Dutch municipalities. Review of Public Personnel Administration, 31(2), 171-189. https://doi.org/10.1177/0734371X11408569

70. Wagenheim, G. D., \& Reurink, J. H. (1991). Customer service in public administration. Public Administration Review, 51(3), 263-269. https://doi.org/10.2307/976950

71. Wilson, A., Zeithaml, V. A., Bitner, M. J., \& Gremler, D. D. (2021). Services marketing: Integrating customer focus across the firm (4th European ed.). McGraw Hill.

72. Wisniewski, M. (2001). Assessing customer satisfaction with local authority services using SERVQUAL. Total Quality Management, 12(7-8), 995-1002. https://doi.org/10.1080/09544120100000026

73. Yashima, T. (2002). Willingness to Communicate in a Second Language: The Japanese EFL Context. The Modern Language Journal, 86(1), 54-66. https://doi.org/10.1111/1540-4781.00136

74. Yonamine M. (1960). Ken'i shugi shakudo ni kansuru ichikenkyu: F Sukeru no kento [A study on the authoritarianism scale: An examination of the F Scale] Kenkyu Shuroku (Ryukyu University), 4, 4353. http://ir.lib.u-ryukyu.ac.jp/bitstream/20.500.12000/19152/1/No4p043.pdf

75. Yu, Z., Bo, W., \& Shu, L. (2011). The dynamic relationship between satisfaction with local government, family income, and life satisfaction in China: A 6-year perspective. International Conference on Management Science \& Engineering 18th Annual Conference Proceedings, 12071214. https://ieeexplore.ieee.org/document/6070109

Note: For Japanese references that do not have official English titles, the English titles provided in parentheses were translated by the author from the original Japanese titles.

\section{Figures}




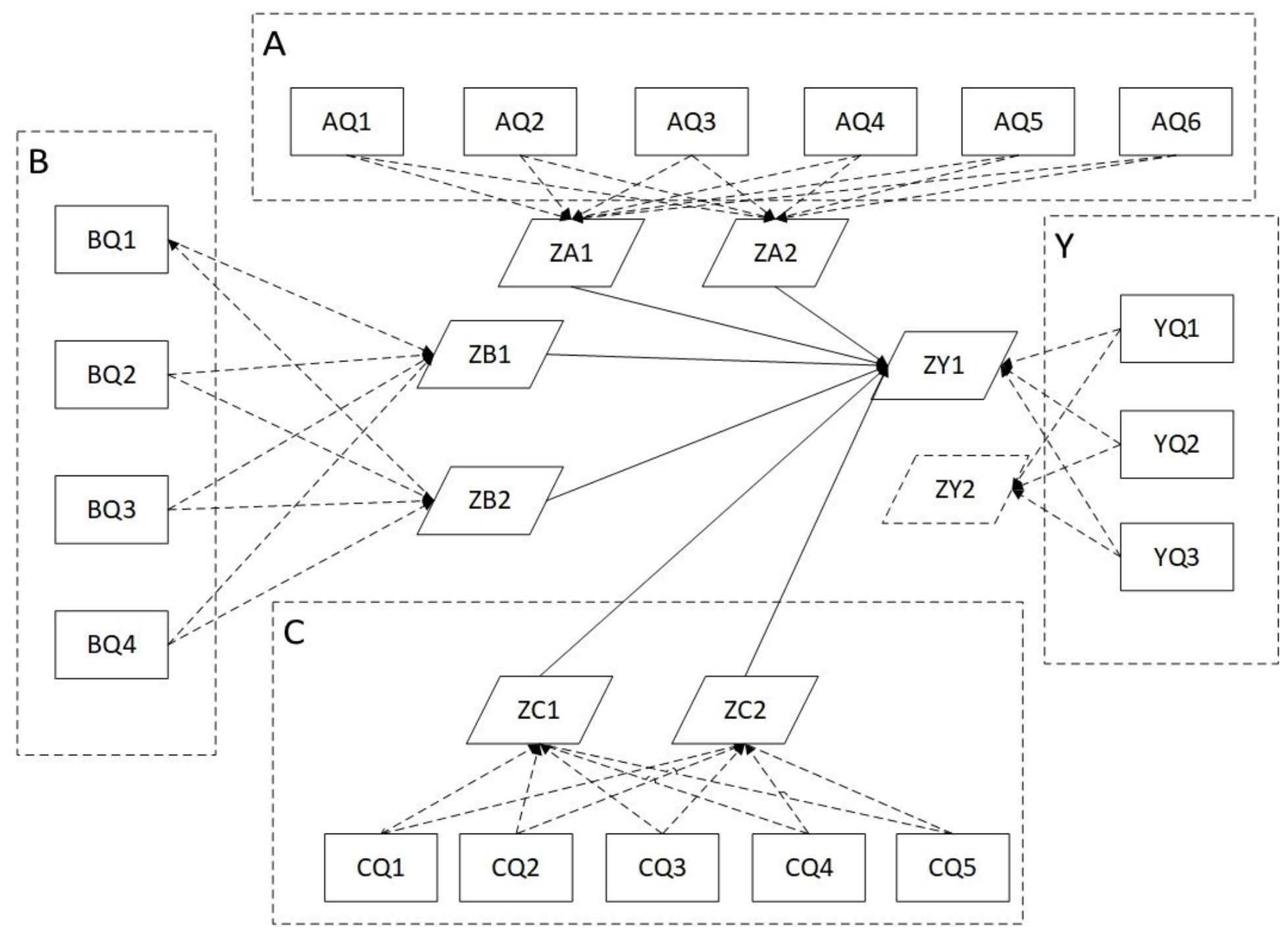

Figure 1

Research analysis model 


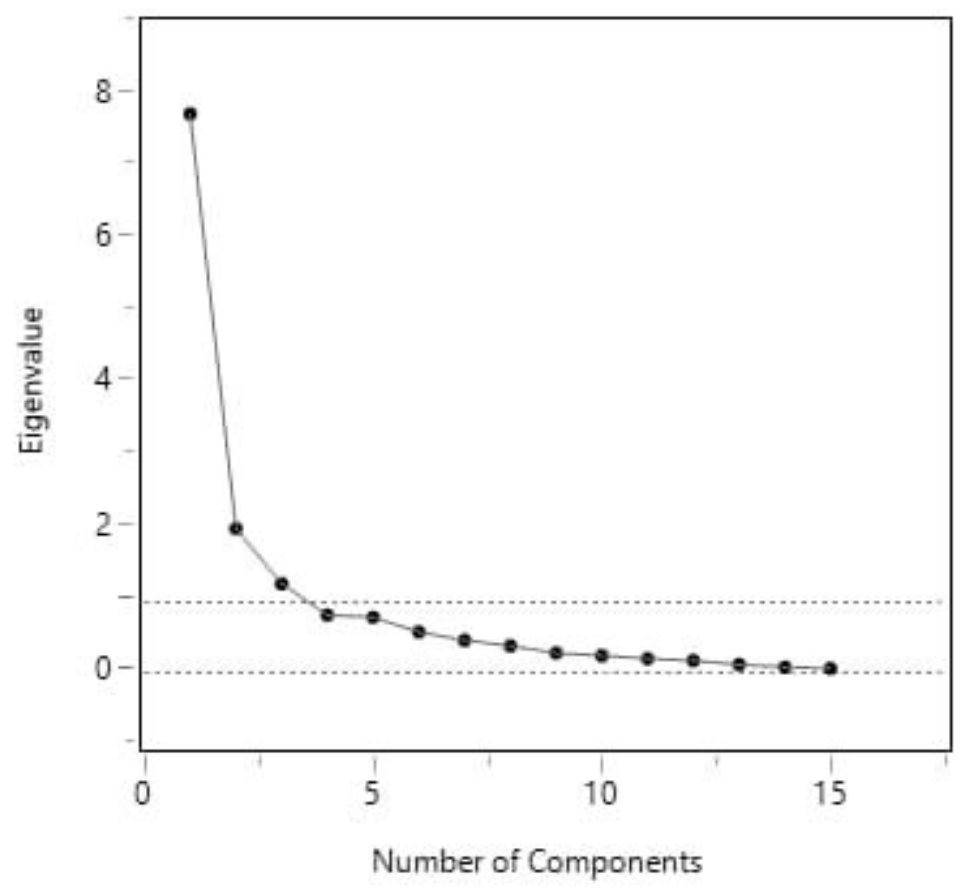

Figure 2

Scree plot of factor analysis

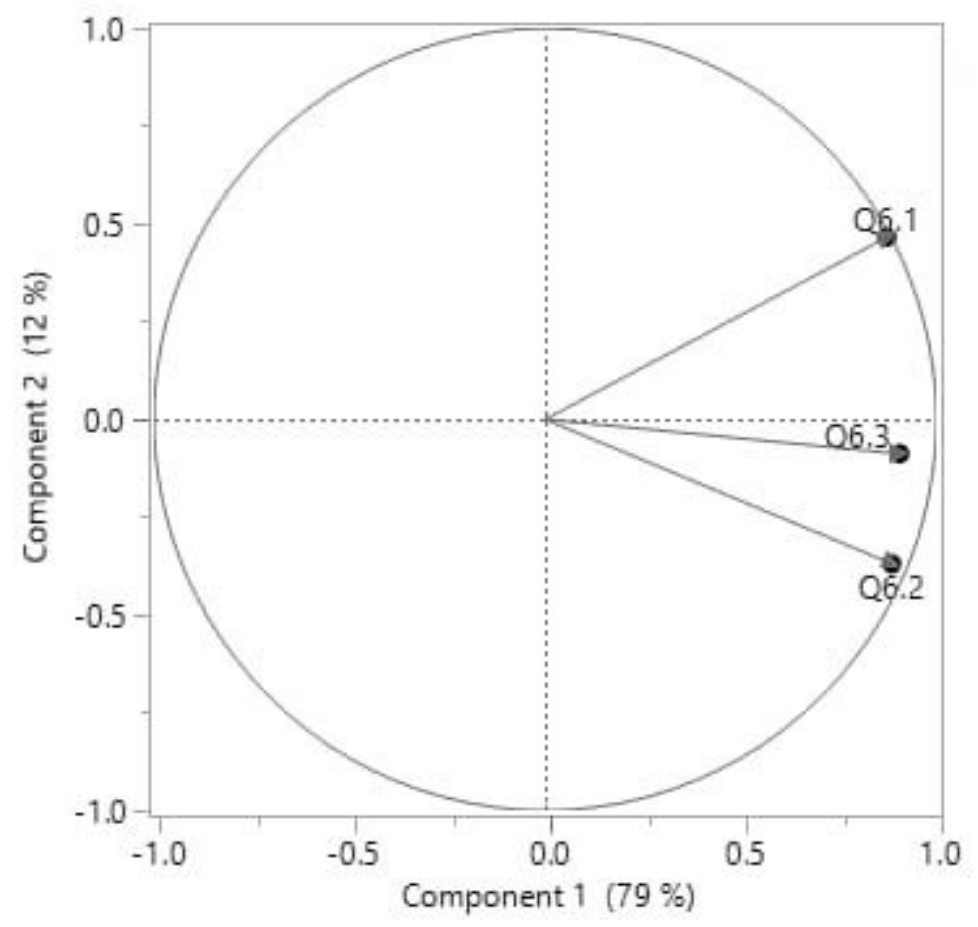

Figure 3

Factor loadings related to $Y$ (overall customer satisfaction with counter services) 


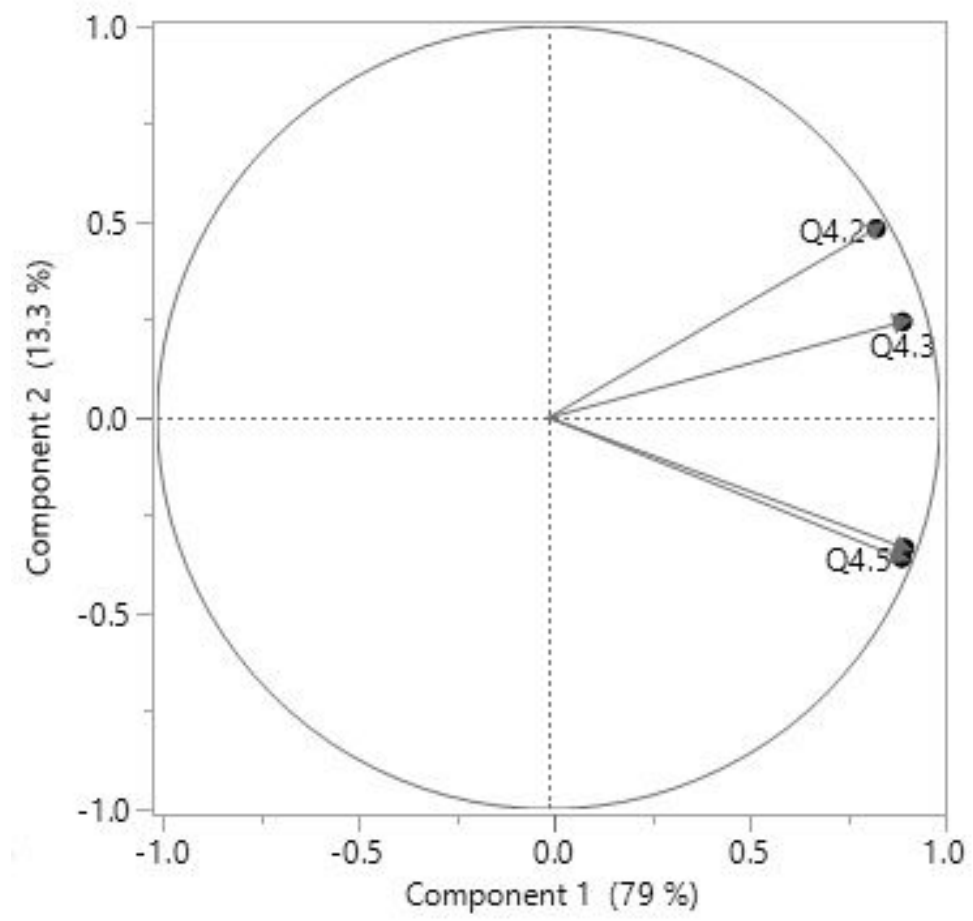

Figure 4

Factor loadings related to $\mathrm{A}$

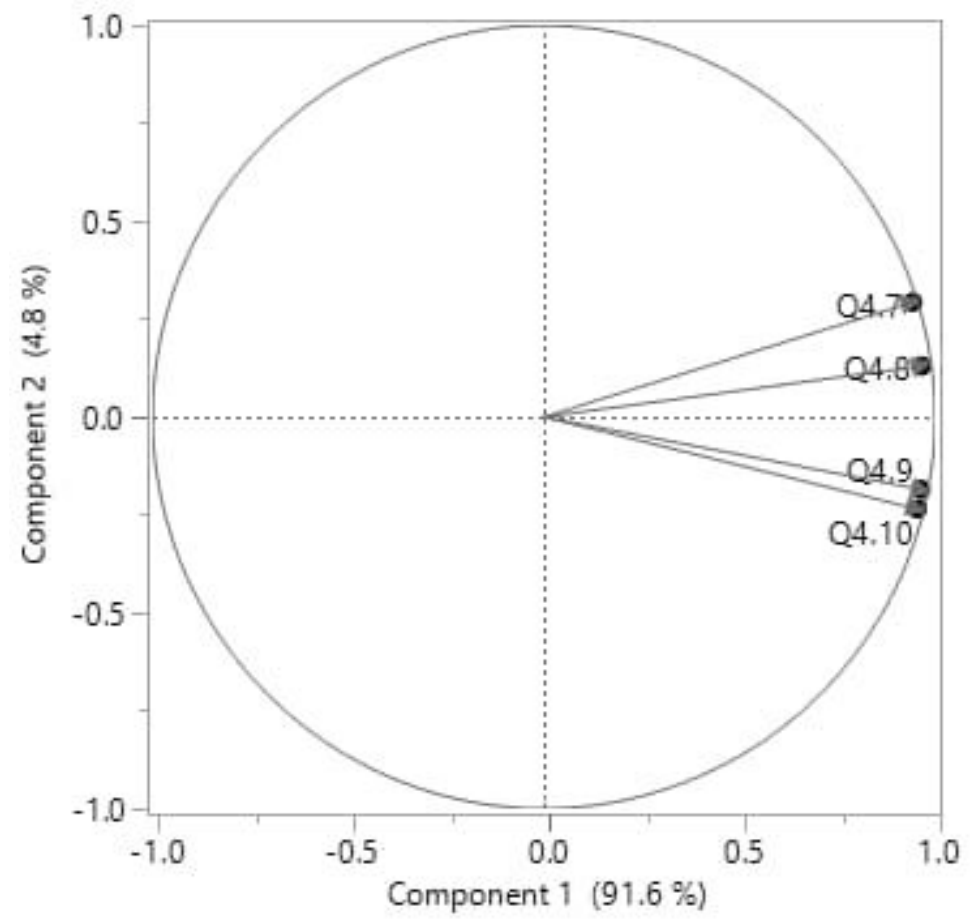

Figure 5

Factor loadings related to $B$ 


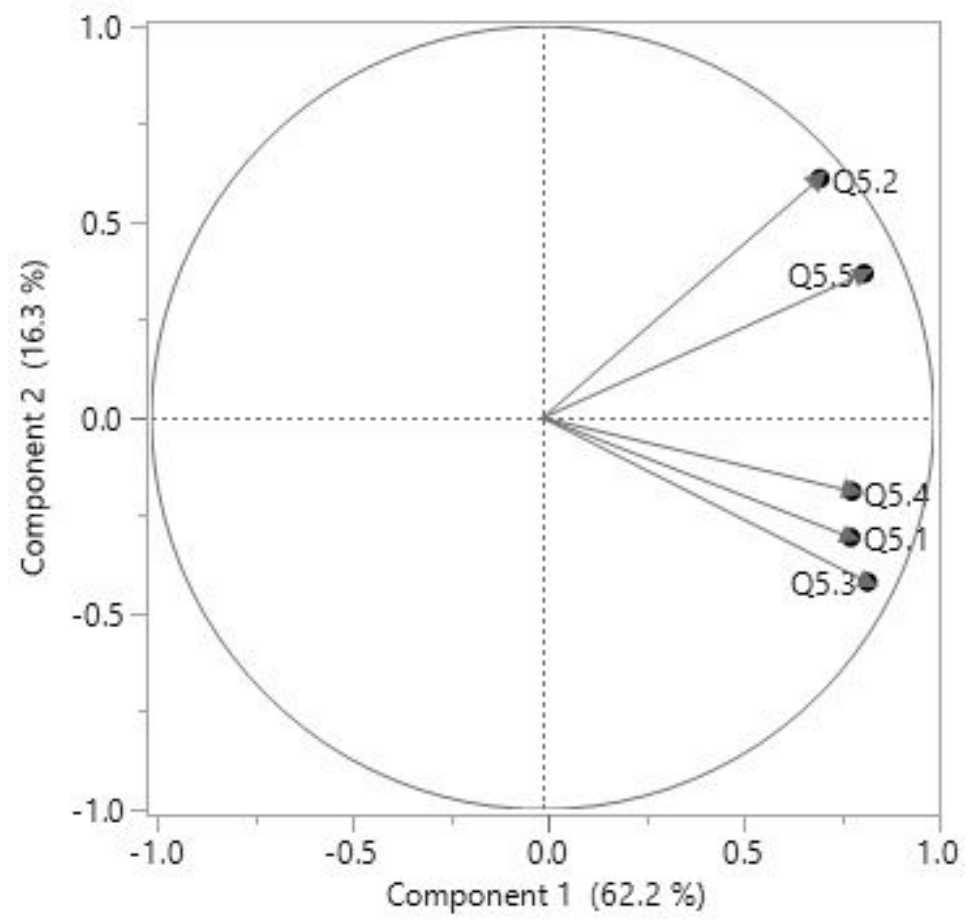

Figure 6

Factor loadings related to $\mathrm{C}$

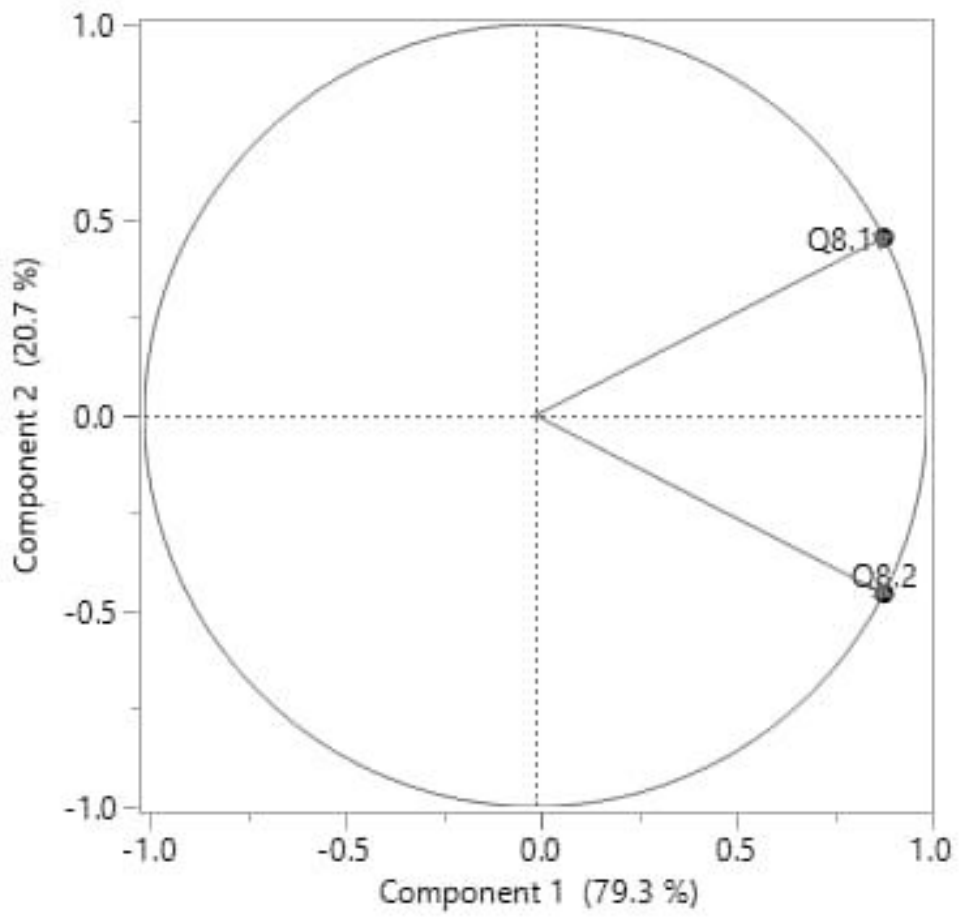

Figure 7

Factor loadings related to $\mathrm{M}$ 


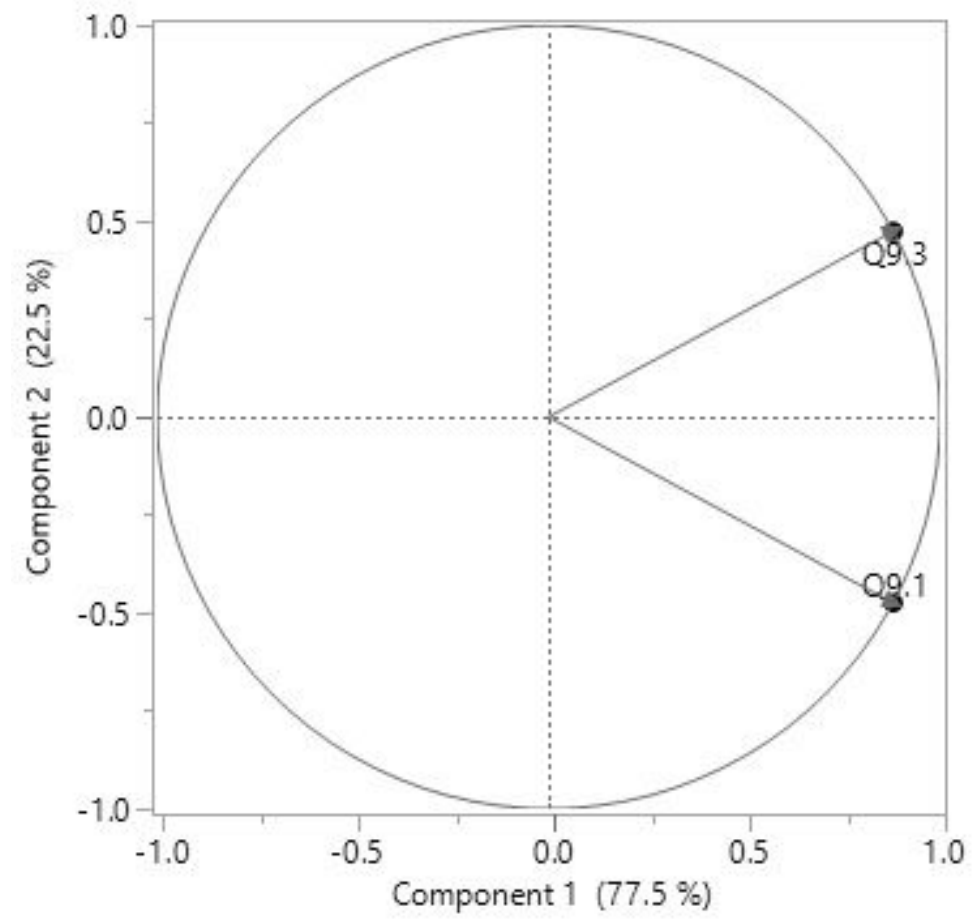

Figure 8

Factor loadings related to I

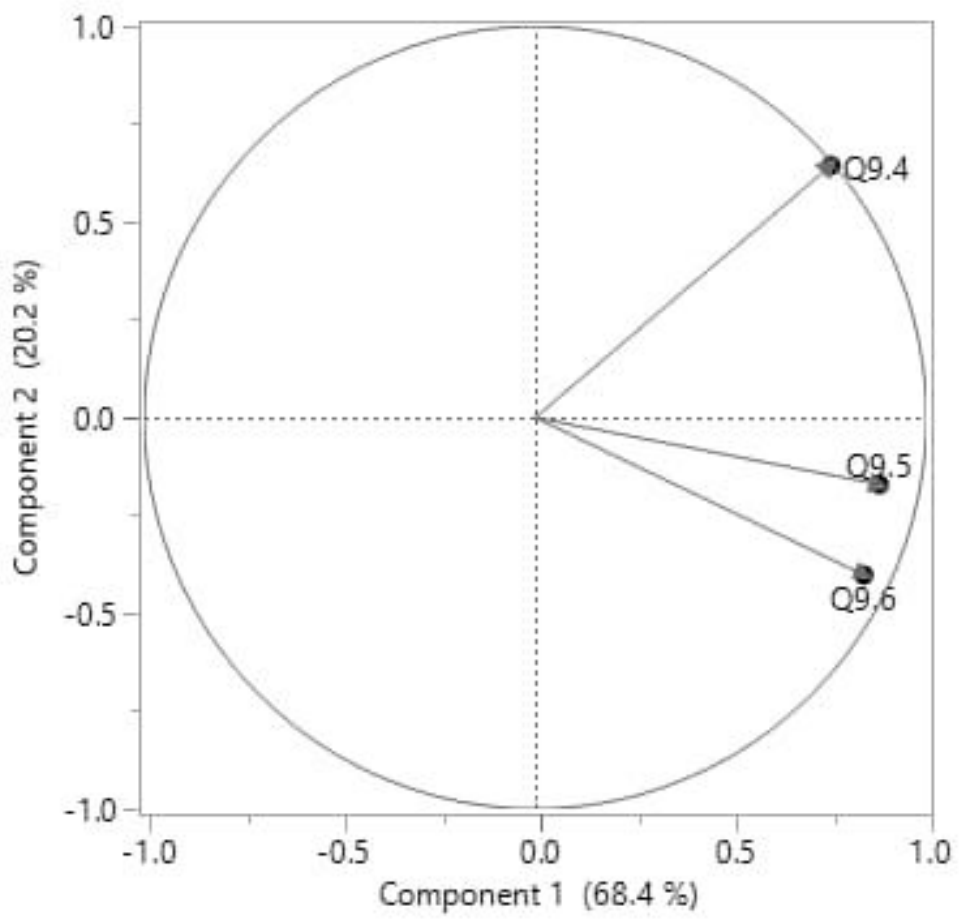

Figure 9

Factor loadings related to $\mathrm{F}$ 